\title{
Philosophiques
}

\section{Livres reçus (automne 1999)}

Volume 26, numéro 2, automne 1999

La critique de la raison en Europe centrale

URI : https://id.erudit.org/iderudit/004952ar

DOI : https://doi.org/10.7202/004952ar

Aller au sommaire du numéro

Éditeur(s)

Société de philosophie du Québec

ISSN

0316-2923 (imprimé)

1492-1391 (numérique)

Découvrir la revue

Citer ce document

(1999). Livres reçus (automne 1999). Philosophiques, 26(2), 397-398.

https://doi.org/10.7202/004952ar

Ce document est protégé par la loi sur le droit d'auteur. L'utilisation des services d'Érudit (y compris la reproduction) est assujettie à sa politique d'utilisation que vous pouvez consulter en ligne.

https://apropos.erudit.org/fr/usagers/politique-dutilisation/
Cet article est diffusé et préservé par Érudit.

Érudit est un consortium interuniversitaire sans but lucratif composé de l’Université de Montréal, l'Université Laval et l'Université du Québec à Montréal. Il a pour mission la promotion et la valorisation de la recherche. https://www.erudit.org/fr/ 


\section{Livres reçus (automne 1999)}

Abécassis, Éliette, Petite métaphysique du meurtre. Paris, PUF (coll. « Perspectives Critiques »), 1998, 106 pages.

Aliquié, Ferdinand, Le rationalisme de Spinoza. Paris, PUF (coll. « Épiméthée »), 1998, 368 pages.

Audart, Catherine, Anthologie historique et critique de I'utilitarisme. IBentham et ses précurseurs (1711-1832). Paris, PUF (coll. « philosophie morale»), 1999, 344 pages. (Aussi volumes 2 et 3).

Badiou, Alain, Saint Paul. La fondation de l'universalisme. Paris, PUF (coll. «Les essais du Collège International de Philosophie»), 1999, 122 pages.

Balibar, Françoise, Galilée, Newton lus par Einstein. Paris, PUF (coll. «Philosophies »), 1999, 128 pages.

Bardout, J ean-Christophe, M alebranche et la métaphysique. Paris, PUF (coll. « Épiméthée »), 1999, 328 pages.

Bollack, Jean, La mort d'Antigone. La tragédie de Créon. Paris, PUF (coll. «Les essais du Collège international de philosophie»), 1999, 136 pages.

Canto-Sperber, Monique (dir.), Philosophie grecque. Paris, PUF (coll. «Premier Cycle»), 1998, 888 pages.

Chrétien, J ean-Louis, L'arche de la parole. Paris, PUF (coll. «Épiméthée »), 1998, 218 pages.

D astur, Françoise, H usserl. D es mathématiques à I'histoire. Paris, PUF (coll. «Philosophies»), 1999, 128 pages.

- - , H eidegger et la question du temps. Paris, PUF (coll. « Philosophies »), 1999, 128 pages.

De Munck, Jean, L'institution sociale de l'esprit. Paris, PUF (coll. « L'interrogation philosophique »), 1999, 206 pages.

Duns Scot, J ean, Prologue de I'O rdinatio. Présentation et traduction annotée de G érard Sondag. Paris, PUF (coll. «É piméthée »), 1999, 436 pages.

Épicure, Lettres et maximes. Paris, PUF (coll. «Épiméthée»), 1999, 328 pages.

Franck, Didier, Nietzsche et l'ombre de Dieu. Paris, PUF (coll. « Épiméthée »), 1998, 480 pages.

$\mathrm{H}$ aar, Michel, La philosophie française entre phénoménologie et métaphysique. Paris, PUF (coll. "Perspectives Critiques»), 1999, 146 pages.

Kymlicka, Will, Les théories de la justice: une introduction. M ontréal, Boréal, 1999, 364 pages.

Kessler, M athieu, Les Antinomies de l'art contemporain. Paris, PUF (coll. «Perspectives critiques », 1999, 240 pages.

Laupies, Frédéric, Leçon philosophique sur autrui. Paris, PUF (coll. «M ajor »), 1999, 138 pages. 
Le Jallé, Éléonore, Hume et la régulation morale. Paris, PUF (coll. « Philosophies »), 1999, 136 pages.

Le Rider, Jacques, N ietzsche en France. De la fin du $x x^{e}{ }^{e}$ siècle au temps présent. Paris, PUF (coll. «Perspectives Germaniques»), 1999, 280 pages.

M arin, Louis, L'écriture de soi. Paris, PUF (coll. «La librairie du Collège international de philosophie»), 1999, 168 pages.

Meyer, M ichel, Pour une histoire de l'ontologie. Paris, PUF (coll. «Q uadrige»), 1999, 176 pages.

M ontavont, Anne, D e la passivité dans la phénoménologie de H usserl. Paris, PUF (coll. «Épiméthée »), 1999, 296 pages.

Pellegrin, $M$ arie-Frédérique, Leçon sur M énon de Platon. Paris, PUF (coll. «M ajor »), 1999, 128 pages.

Ravaison, Félix, De I'habitude M étaphysique et morale. Paris, PUF (coll. «Quadrige »), 1999, 204 pages.

Vernes, Jean-René, L'existence du monde extérieur et l'erreur du rationalisme. Québec, Les Presses de I'Université Laval, 1999, 103 pages.

Les personnes désireuses de faire un compte-rendu de l'un ou l'autre des ouvrages qui apparaissent dans cette liste sont priées de s'adresser à :

Daniel Dumouchel Université de M ontréal

Département de philosophie

C.P. 6128 Succ. Centre-ville

M ontréal, Q uébec, H 3C 3J 7

tél: (514) 343-6484

télec: (514) 343-7899

Courriel: dumouchd@ere.umontreal.ca 